\title{
De la separatism regional la centralizare: două proiecte legislative ale universitarilor clujeni privind reforma învățământului superior românesc după 1918
} Ana-Maria STAN

\begin{abstract}
After the Great War and the union of Bessarabia, Bukovina, Transylvania, and the Banat with the Old Kingdom, the reform of higher education and, implicitly, its transformation into a unitary and efficient system required a lot of efforts. A significant number of initiatives and projects were discussed by the Romanian academic circles, politicians, and by the broader public before the first law for the organization of universities in Greater Romania was adopted and implemented, in April 1932. This article is a case study, which focuses on two proposals put forward in the 1920s by some prominent professors of the University of Cluj. My research tries to clarify and enrich our knowledge regarding the various stages that preceded and shaped the 1932 higher education law. It highlights the similarities and differences between these projects, looking, in particular, at their most relevant and modern elements. The article could equally provide points of comparison for future analysis regarding the reconstruction of the educational systems in other Central or Eastern European countries, in the first half of the $20^{\text {th }}$ century.
\end{abstract}

Keywords: Romanian university reform, interwar period, legislative initiatives, Romanian University of Cluj, Emil Racoviță, 1932 Law on higher education.

Integrarea administrativă și sincronizarea funcționării instituțiilor după unirea Basarabiei (27 martie/ 9 aprilie 1918), a Bucovinei (15/ 28 noiembrie 1918), a Transilvaniei și Banatului (1 decembrie 1918) cu vechiul Regat al României a reprezentat un proces îndelungat și complex, iar domeniul educațional nu a făcut nici el excepție de la regulă. Nu doar Parlamentul și politicienii s-au implicat în acest demers, ci și presa vremii sau diferitele organizații profesionale au dezbătut intens cele mai potrivite soluții de funcționare pentru fiecare nivel de instrucție (primar, secundar, universitar). Dintre toate, reformarea învățământului superior și, implicit, transformarea acestuia într-un sistem deopotrivă unitar și performant a necesitat cele mai multe eforturi, cea dintâi lege pentru organizarea universităților din România Mare fiind adoptată și pusă în aplicare abia în aprilie 1932 .

Deși negocierile pe acest subiect au început aproape imediat după Primul Război Mondial, durata lor și dificultatea cu care s-a ajuns la un consens sunt parțial explicabile tocmai prin diversitatea structurilor academice de pe teritoriul statului român. În octombrie 1922, un document aflat în dezbatere la Adu- 
narea Deputaților, descria situația în următorii termeni: „în România întregită avem astăzi patru universități și o Academie de Drept; ele se găsesc însă sub regimuri legale diferite. Pe când la Universitățile din București și Iași se aplică legea învățământului nostru superior, Universitatea din Cernăuți se conduce după legile austriace, iar Universitatea din Cluj și Academia din Oradea-Mare nu recunosc decât legislația ungară. Din această cauză, o sumă de greutăți în conducere și de anomalii în aplicare..." . Primul rector al Universității românești din Cluj, profesorul Sextil Pușcariu², exprimase și el o opinie similară în 1919, la scurt timp după instalarea sa în funcție: „Alcătuirea internă a universității noastre este $[. .$.$] cea moștenită de la înaintașii noștri, rămânând ca ea să se modifice$ deodată cu reforma învățământului superior din România întregită. Din deosebirea ce există între organizația universităților din Vechiul Regat - în cea mai mare parte alcătuite după tipul francez - și al universității noastre - care, ca și cea din Cernăuți, are tipul german - au rezultat multe neajunsuri. [...] De aceea, ținând la unele forme vechi, fără să ne simțim atinși de reproșul de separatism regional, am alcătuit noile regulamente ale facultăților, luând ca bază pe cele din Vechiul Regat și modificându-le numai întrucât ni se par că nu mai corespund cerințelor”3. Așa cum arată și Walter Ruegg în lucrarea sa monumentală privind istoria universităților europene, Vechiul Regat al României era într-adevăr singura țară de pe continent care își organizase sistemul academic după modelul francez (a se înțelege napoleonian), și care menținuse traiectoria impusă de acesta dinspre studiile universitare către o funcție publică, în timp ce în restul Europei, la finalul secolului secolului XIX-lea și începutul secolului al XX-lea predomina modelul german de universitate, adică humboldtian, bazat pe stimularea gândirii științifice, orientată către cercetări și descoperiri, dar și pe ideea de libertate sau autonomie academică ${ }^{4}$.

1 Diana-Gabriela Reianu, Politica educațională românească în dezbaterile parlamentare, 19191929 (Cluj-Napoca: Presa Universitară Clujeană, 2018), 101.

2 Sextil Pușcariu (1877-1948), filolog român, specializat în lingvistică și istorie literară. Între 1906-1918 a fost profesor titular de limba și literatura română la Universitatea din Cernăuți (pe atunci universitate de limbă germană, parte a sistemului academic din Imperiul Austro-Ungar). Din primăvara lui 1919 a fost chemat în România Mare, la Cluj, unde a prezidat Comisiunea Universitară, care s-a ocupat de transformarea universității din localitate în instituție academică românească. În anul universitar 1919-1920 a fost ales rector al noii Universității românești de la Cluj, funcție pe care a deținut-o și între 1940-1941. Între 19191947 a fost profesor titular de limba și literatura română la Cluj. Membru al Academiei Române (membru corespondent din 1905, membru titular din 1914).

3 Sextil Pușcariu, Memorii (București: Editura Minerva, 1978), 417 și 419.

4 Walter Ruegg, ed., A history of the university in Europe. Volume III - Universities in the nineteenth and early twentieth centuries (1800-1945) (Cambridge/ New York: Cambridge University Press, 2004), 4-10. 
Pornind de la premisele menționate mai sus, nu este de mirare că anii interbelici abundă în iniţiative și proiecte care și-au propus să ofere soluții de armonizare a vieții universitare românești. Toți actorii sistemului academic, atât cei vechi (adică universitățile din Iași și București), cât și cei mai noi (adică universitățile din Cluj și Cernăuți) s-au implicat activ în elaborarea de modele de lucru comune, dar și eficiente, pentru învățământul superior. Uneori, proiectele aparțineau instituției, alteori erau rodul unei munci de echipă (a 2-3 colegi) sau chiar inițiative individuale, ale anumitor profesori universitari, care dețineau și funcții politice (ca de exemplu P. P. Negulescu - ministru al Instrucțiunii Publice între martie 1920 și decembrie 1921, în timpul guvernului Averescu ${ }^{5}$ ). Parlamentul României avea să discute în repetate rânduri tema reformei universităților, cei mai vocali fiind, în mod firesc, deputaţii ori senatorii care veneau din mediul universitar. Dezbaterile au fost purtate și la nivelul organizațiilor profesionale, ca de exemplu în Asociația Profesorilor Universitari din România ${ }^{6}$ sau în cadrul societăților studențești. Presa generalistă și cea cultural-științifică a reflectat și ea pe larg subiectul, secondată fiind de ziarele și revistele publicate de studenți.

Analiza noastră este un studiu de caz, care discută două propuneri făcute de către universitarii de la Cluj pe acest subiect. Universitatea clujeană reprezintă un reper în domeniu, ea fiind practic reînființată după 1918 ca instituție academică românească în urma unei transformări etapizate, organizate temeinic, dar și destul de rapid 7 . Această metamorfoză s-a desfășurat în perioada 12 mai 1919-2 februarie 1920. Astfel, la 12 mai 1919, o comisie coordonată de către Onisifor Ghibu, pe atunci secretar general al Resortului (Ministerului) Cultelor și Instrucțiunii Publice din cadrul Consiliului Dirigent, a preluat în administrarea autorităţilor române întreg patrimoniul mobil și imobil al universității maghiare din Cluj. Cursurile în limba română s-au deschis în 3 noiembrie 1919, prelegerea inaugurală, intitulată „Datoria vieții noastre”, fiind rostită de profesorul Vasile Pârvan, de la Universitatea din București. Universitatea funcționa cu patru facultăţi: Drept, Medicină, Litere și Filozofie, Științe, și cu un corp profesoral aproape exclusiv românesc, cu toate că printre studenții înscriși la cursuri s-au regăsit și destui reprezentanți ai minorităților care trăiau în Transilvania:

5 P. P. Negulescu, Reforma învățământului. Proiecte de legi, ediția a II-a (București: Editura Casa Școalelor, 1927).

6 Ana-Maria Stan, „Universitarii în conclav: congresele Asociației Profesorilor Universitari din România în Clujul interbelic”, in Fragmente de pe un câmp de luptă: studii în istoria universității, eds. Florea Ioncioaia, Leonidas Rados (Iași: Editura Universității Alexandru Ioan Cuza, 2018), 339-364.

7 Vasile Pușcaș, Universitate, societate, modernizare. Organizarea și activitatea științifică a universității din Cluj,1919-1940, ediția a II-a (Cluj-Napoca: Ed. Eikon, 2003), 79-245. 
maghiari, evrei, germani. Ultimul episod important din procesul de fondare a universității românești din Cluj s-a derulat între 31 ianuarie-2 februarie 1920, când au avut loc Serbările oficiale de inaugurare ale universității, în prezența Regelui Ferdinand I, a reginei Maria a României, precum și a numeroase personalități românești și străine. $\mathrm{Cu}$ această ocazie, Regele Ferdinand I a donat suma de 400.000 de lei din propria avere pentru înființarea unui „Institut pentru studiul istoriei române, atât de vitreg tratată sub stăpînirea trecută”8.

Clujul deținea așadar o poziție privilegiată în sistemul universitar românesc, nu doar pentru că era singura instituție de acest tip din Transilvania (cea mai mare și mai relevantă provincie recâștigată după război atât pentru mentalul colectiv național, cât și pentru autoritățile statului român), ci și fiindcă era percepută și se percepea ea însăși drept un model, un ,exemplu pentru cum trebuie făcută unificarea" ${ }^{\prime}$. În prezent, există puține cercetări care s-au concentrat asupra transformărilor sistemului educațional din România anilor 1918-1940, și mai ales asupra etapelor și dezbaterilor care au dus la modernizarea acestuia, a mecanismelor și factorilor de influență care au făcut să se prefere anumite soluții în detrimentul altora. Iată de ce analiza inițiativelor legislative pornite de la Cluj pe tema reformei învăţământului superior este importantă pentru a completa imaginea societății românești din perioada interbelică. Acest studiu de caz oferă celor interesați informații care pot clarifica unele aspecte privind funcționarea (și funcționalitatea) statului, precum și raporturile care se stabiliseră între diferite grupuri socio-profesionale și anumite structuri sau autorități administrative.

În cele ce urmează vom examina câteva puncte cheie, și anume:

1. Cine și în ce mod s-a implicat în redactarea și/sau discutarea planurilor de reformă educațională;

2. În ce măsură tradiția academică anterioară se reflectă în documentele elaborate la Cluj;

3. Care sunt elementele de continuitate și/sau de fractură de la un tip de proiect la altul;

4. Câte din ideile sugerate de universitarii clujeni au fost preluate în textul legii din 1932.

Unul dintre primele texte redactate de profesorii clujeni a fost cel intitulat Anteproect de lege a învățământului superior întocmit de Universitatea din Cluj. Deși existent sub formă tipărită, nu manuscrisă sau dactilografiată, despre data

8 Serbările pentru inaugurarea universității române din Cluj 31 ianuarie - 2 februarie 1920 (București: Cartea Românească, 1920), 17.

9 Sextil Pușcariu, Cuvânt de deschidere rostit la al doilea congres al Asociației [profesorilor universitari] la Cluj în 3 iunie 1921 (Cluj: Cartea Românească, 1921), 11. 
exactă a elaborării acestuia avem puține indicii. Documentul de 22 de pagini, aflat în colecțiile Bibliotecii Centrale Universitare „Lucian Blaga” din ClujNapoca, nu are menționate editura, tirajul sau anul publicării, însă este posibil ca de-a lungul timpului coperta și filele de început să fi fost distruse/pierdute. Intrat în fondul de carte ca parte a unei donații făcute de doamna profesor Viorica Lascu, fiica profesorului universitar Alexandru Borza, el a fost datat de specialiștii bibliologi, pe baza informațiilor obținute de la donatoare, cu anul 1923. Totuși, o privire mai atentă asupra celor 108 articole ale anteproiectului pune sub semnul întrebării această situare cronologică.

În opinia noastră, documentul a fost elaborat și tipărit ceva mai târziu, mai exact, în perioada 1924-1926, fapt susținut de anumite detalii din conținutul documentului. Astfel, secțiunea a XI-a, în speță art. 90-92 ale anteproiectului sunt dedicate Extensiunii Universitare și activității ei. Or, este binecunoscut că Extensiunea Universitară, atât ca denumire specifică, cât și ca structură de sine stătătoare, a fost înființată la Universitatea din Cluj abia în toamna lui 1924, la iniţiativa și sub directa îndrumare a profesorului Virgil Bărbat, sociolog, și a colegilor săi de la Facultatea de Litere, printre care îi menționăm aici pe filologul Vasile Bogrea, psihologul Florian Ștefănescu-Goangă și istoricul Silviu Dragomir $^{10}$. Coroborăm ideea că Anteproectul de lege... este posterior anului 1923 și cu faptul că, în vara anului 1925, orașul Cluj a găzduit Congresul anual al Asociaţiei Profesorilor Universitari din România (A.P.U.R.), iar în cadrul acestuia, una dintre temele abordate a fost tocmai chestiunea reformei sistemului de învățământ superior din întreaga Românie. Cu această ocazie, profesorii Emil Racoviță ${ }^{11}$ și Dimitrie Călugăreanu ${ }^{12}$ au alcătuit și prezentat spre dezbatere, în fața tuturor participanților, un anteproiect de lege ${ }^{13}$. Aceste două argumente ne conduc la concluzia că Anteproectul la care ne referim poate fi datat mai degrabă cu 1925, decât cu anul stabilit de bibliotecarii clujeni.

${ }^{10}$ Virgil Bărbat, Florian Ștefănescu-Goangă, eds., Extensiunea Universitară (Cluj: 1926).

${ }^{11}$ Emil Racoviță (1868-1947), biolog, speolog și explorator român. Profesor universitar de biologie la Universitatea românească din Cluj între 1919 și 1947, rector al acesteia în anul universitar 1929-1930. În aprilie 1920 a fondat Institutul de Speologie de la Cluj, la acea vreme primul de acest fel din lume. Membru al Academiei Române din 1905 și președinte al acesteia în perioada 1926-1929.

12 Dimitrie Călugăreanu (1868-1937), fiziolog și naturalist român. Profesor universitar de fiziologie animală la Universitatea românească din Cluj (1919-1926), transferat apoi la Universitatea din București. Rector al universităţii clujene în anul universitar 1921-1922. Din 1920 membru corespondent al Academiei Române.

${ }^{13}$ Asociația profesorilor Universitari din România (A.P.U.R.), Adunarea generală din anul 1925, ținută la Cluj. Dare de seamă (Cluj: Institutul de Arte Grafice Ardealul, 1926), 14; Stan, „Universitarii în conclav", 349-350. 
Aceleași indicii ne permit, de asemenea, să lansăm câteva ipoteze referitoare la autorii Anteproectului..., sau la semnatarii săi, detalii importante, care lipsesc din paginile documentului. Este întemeiat să presupunem că un astfel de text putea să fie elaborat, în special, de către universitarii cu experiență administrativă, respectiv rector, decani sau prodecani, alături de șefi ai unor institute, laboratoare, catedre, etc. La acel moment, Clujul împlinise deja cinci ani de funcționare ca instituție academică românească, timp suficient pentru a-și dovedi viabilitatea științifică și didactică. În pofida anumitor tensiuni etnice care i-au perturbat temporar activitatea (ne referim aici la tulburările studențești antisemite declanșate în toamna lui 1922, comune de altfel întregii Românii, și chiar Europei centrale, în acea epocă $\left.{ }^{14}\right)$, Clujul începea să se impună pe harta academică a țării, oferind deja primele generații de specialiști. Dintre opiniile care recunoșteau reuşitele acestei noi universități o cităm aici pe cea a lui Onisifor Ghibu, unul dintre cei mai atenți și avizați observatori ai sistemului educaţional şi pedagogic românesc de după 1918. În 1924, Ghibu spunea: „activitatea acestor cinci ani este o carte deschisă pentru oricine și această carte face onoare neamului nostru înaintea lumii întregi. [...] Sub raportul organizării, universitatea românească din Cluj nu este o simplă continuare a vechii universități ungurești. Noi n-am schimbat numai firma și limba vechiului așezământ; noi am creat și forme noi pe lângă spiritul larg pe care l-am adus. O serie întreagă de institute și de catedre noi s-au adăugat la cele existente. [...] În ce privește activitatea științifică a profesorilor, ea a întrecut în unele privințe toate așteptările. [...] Aceasta a avut fericirea să fie ajutată și de unii colegi străini, care nu s-au sfiit să se înșiruie alături de tinerele forțe ale Ardealului și să lucreze mână în mână cu acestea pentru promovarea științei. Astfel au fost contribuțiile dlor. E. de Martonne de la Sorbona, dr. Levaditi de la Facultatea de Medicină din Paris, H. Focillon și Guyart de la Lyon, precum și ale profesorilor de la celelalte universități române: V. Pârvan, D. Pompeiu, George Murgoci, dr. Victor Babeș, dr. George Marinescu, dr. G. Leon, dr. Ioan Cantacuzino, care au venit în mijlocul nostru pentru a ține cursuri pentru studenții clujeni”'15.

În anul universitar 1924-1925 conducerea Universităţii clujene era compusă din: profesorul Camil Negrea - rector, Nicolae Bănescu - prorector,

${ }^{14}$ Ana-Maria Stan, "The 1922-1923 Student Revolts at the University of Cluj, Romania: From Local Anti-Semitic Academic Protests to National Events”, in Student Revolt, City, and Society in Europe, ed. Pieter Dhondt, Elizabethanne Boran (New York/London: Routledge, 2017), 286-303; Lucian Năstasă-Kovacs, Antisemitismul universitar în România (1919-1939). Mărturii documentare (Cluj-Napoca: Ed. ISPMN/ Kriterion, 2011).

${ }^{15}$ Onisifor Ghibu, Universitatea românească a Daciei superioare, cu prilejul împlinirii a cinci ani de activitate (Cluj: Tipografia Viața, 1924), 18-23. 
Petre Poruțiu - decan al Facultății de Drept, Iuliu Moldovan - decan al Facultăţii de Medicină, Virgil Bărbat - decan al Facultății de Litere și Filozofie, George Spacu - decan al Facultății de Științe, alături de prodecanii Romulus Boilă (Drept), Dimitrie Negru (Medicină), Nicolae Drăganu (Litere și Filozofie), George Bratu (Științe) ${ }^{16}$. Marea majoritate dintre ei erau și membri ai filialei clujene a A.P.U.R. încă de la înființarea acesteia, în mai $1920^{17}$, deci erau la curent cu temele care îi interesau pe membrii comunității academice. Acestor universitari li s-au adăugat cu siguranță și alți colegi clujeni, personalități cu influență pe plan național sau internațional, precum Emil Racoviță, Sextil Pușcariu, ori Alexandru Lapedatu ${ }^{18}$, ministru al Cultelor și Artelor între octombrie 1923 - martie 1926, în guvernul liberal condus de Ion I.C. Brătianu.

Revenind la conținutul Anteproectului de lege..., o analiză detaliată ne oferă date interesante despre viziunea profesorilor din Transilvania asupra învățământului superior din România Mare. Prima observație în acest context este că aceștia aveau o privire integrativă asupra problemei, căci textul se ocupa de toate aspectele vieții academice și de întreaga comunitate din Alma Mater. Cele paisprezece capitole ale documentului iau în discuție atât structura internă, drepturile și obligațiile corpului didactic și ale studenților, cât și alte lucruri importante, ca, de exemplu, chestiunea publicaţiilor universitare sau cea a bibliotecilor universitare. $\mathrm{O}$ atenție deosebită, explicabilă în contextul în care universitatea clujeană se afla la început de drum ca instituție românească, a fost acordată problemei clădirilor în care urma să se desfășoare activitatea de predare și de cercetare, dar și implicării academice în viața publică (a se vedea secțiunea dedicată Extensiunii Universitare, deja pomenită).

${ }^{16}$ Selectați în vara lui 1919 de către Comisiunea Universitară pentru a ocupa catedrele vacante de la Cluj, cei mai mulți dintre ei erau ardeleni școliți la universități din Occident (în special din fostul Imperiu Austro-Ungar, Germania, Franța și Italia), iar alții veniseră de la Universitatea din Iaşi (de exemplu chimistul Gheorghe Spacu sau matematicianul Gheorghe Bratu) și de la Universitatea din București, tocmai pentru a asigura necesarul de cadre didactice al noii instituții. Cu una sau două excepții, corpul didactic care activase la Universitatea maghiară din Cluj înainte de 1918 a părăsit in corpore România și s-a refugiat în Ungaria, unde și-a continuat activitatea în cadrul Universității Francisc Iosif de la Szeged.

${ }^{17}$ Stan, „Universitarii în conclav”, 341, 348-349.

${ }^{18}$ Alexandru Lapedatu (1876-1950), istoric și om politic român. Membru titular al Academiei Române din 1918. Între 1919-1938 a fost profesor de istorie veche a României la Universitatea din Cluj. Alături de Ioan Lupaş a fondat în 1920 Institutul de Istorie Naţională de la Cluj, pe care l-a și condus în tandem cu colegul său până în 1938. A deținut și numeroase funcții politice, din partea Partidului Național Liberal: a fost de mai multe ori deputat și senator în Parlamentul României şi a avut mai multe mandate de ministru al Cultelor şi Artelor sau ministru de stat în guvernele din anii 1920 și 1930. 
Autorii anteproiectului își deschid textul cu o afirmație îndrăzneață, care recunoștea o realitate deja existentă în spațiul românesc și care reprezenta totodată unul din punctele cele mai sensibile pentru reforma și uniformizarea sistemului educațional, anume faptul că ,învățământul superior se predă în: a) universități și institute tehnice universitare și b) școli superioare speciale $c u$ caracter universitar [s.n.]” (art. 1). Ulterior, în art. 3, se făcea precizarea că școlile superioare cu caracter universitar erau Academia de Drept de la Oradea, respectiv, Academia Comercială din Clujj ${ }^{19}$. Această „radiografiere” instituțională impune deja câteva comentarii. Pe de o parte, ar trebui observat faptul că, la început de secol XX, în România existau mai multe categorii de școli care asigurau pregătire de nivel superior, terțiar, însă nu toate aveau competențele ori se bucurau de prestigiul universităților propriu-zise. Acest mediu concurențial a provocat, de altfel, îndelungi dezbateri privind subiecte precum Ce este o universitate?, dacă academiile sau școlile speciale (tehnice, artistice, agricole, comerciale, silvice etc.) puteau fi considerate ca atare, și cum avea să fie selectat și salarizat personalul din cadrul lor. Legea din aprilie 1932 va îmbrățișa parțial viziunea din Anteproectul de lege... și va menține hegemonia universităților față de restul școlilor superioare și/sau academiilor. Definite drept ,așezăminte de învățământ universitar teoretic și aplicat, precum și instituţiuni de cercetări pentru progresul științei și răspândirea culturii”20, universitățile beneficiau așadar de un statut privilegiat. Această diferențiere clară dintre universități și alte tipuri de școli superioare și/ sau academii, păstrată de sistemul educațional interbelic, reflectă în parte conflictul dintre modelul german și cel francez de pregătire academică, precum și o anumită concepție privind controlul pe care statul român dorea să îl exercite asupra acestui domeniu. Putem adăuga aici și alte mize de natură financiară sau chiar social-politică (în sensul că universitarii doreau să fie percepuți ca elită, ca resursă de expertiză pentru toate instituțiile și structurile publice).

Pe de altă parte, limitarea listei de școli superioare doar la cele care funcționau în Transilvania indică, în opinia noastră, fie o abordare voit unilaterală, regionalistă a situației, fie o destul de mare lipsă de informare, ca să nu spunem necunoaștere a situației generale, din toate provinciile românești, în privința unor asemenea instituții. Evident, există și posibilitatea să se fi urmărit ca evidența acestor școli să fie completată ulterior, deci extinsă, cu sprijinul

${ }^{19}$ Anteproect de lege a învăţământului superior întocmit de Universitatea din Cluj (Cluj, [1925?]), 3.

${ }^{20}$ Antologia legilor învățământului din România (București: Institutul de Științe ale Educației, 2004), 257. 
colegilor din alte centre universitare din țară și numai după o reflecție atentă asupra trăsăturilor lor specifice, mai precis, asupra acelui „,caracter universitar”, pe care însă anteproiectul nu îl definea deloc.

Un alt element extrem de important și subliniat încă de la început în textul redactat la Cluj în prima jumătate a anilor 1920 se referă la autonomia universitară - în fapt, la soclul pe care trebuia clădită întreaga funcționare instituțională a universităților. Autonomia urma să cuprindă, printre altele, „dreptul de a propune numirea personalului didactic, administrativ şi al personalului de serviciu, inviolabilitate, dreptul de a rechiziționa forța publică (...), dreptul de a trimite un senator în Parlamentul Țării sau executarea [proprie] a legii bugetare”21. Considerăm că referința la dreptul de a trimite reprezentanți în Parlamentul Țării reprezintă în fapt o corelare între dorința universitarilor de a li se recunoaște un statut socio-profesional special, privilegiat (de înalt funcționar public), și prevederile deja existente în Constituția din 1923 care, la secțiunea II, art. 71, menționa că „fiecare universitate alege, din sânul sau, prin votul profesorilor săi, câte un senator" ${ }^{22}$. Acesta este, de atfel, un alt indiciu că textul anteproiectului clujean a fost redactat după adoptarea legii fundamentale a țării.

La fel ca și definiția universităților, și noțiunea de autonomie universitară avea să fie discutată constant în perioada interbelică, atât în Parlament, cât și în mediul academic ori în mass-media, iar limitele și modalităţile ei concrete de aplicare vor fi (re)definite în aproape toate propunerile și planurile legislative interbelice și încununate prin adoptarea în iulie 1931 a legii pentu autonomia universitară, în elaborarea căreia un rol esențial l-a avut Constantin Kirițescu, consilier pentru învățământul superior din Ministerul Instrucțiunii Publice ${ }^{23}$.

Din punct de vedere organizatoric, anteproiectul exprima atât idei sincrone cu tendințele europene ale vremii, cât și un anumit atașament față de tradiția academică anterioară, când Alma Mater de la Cluj a funcționat după regulile existente în cadrul Imperiului Austro-Ungar.

Păstrând ideea separării pe facultăți de profil, universitarii clujeni au prevăzut ca funcționarea instituțională să se desfăşoare în cadrul mai multor unități distincte, anume: „,catedre de științe teoretice, catedre de științe experimentale, servicii de cercetări, institute și oficii universitare" ${ }^{24}$. Componentele noi, inovatoare, din această enumerare sunt serviciile de cercetări şi

\footnotetext{
${ }^{21}$ Anteproect de lege, 3.

${ }^{22}$ Constituția din 1923, http://legislatie.resurse-pentru-democratie.org/constitutie/constitutiunea-din-1923.php.

${ }^{23}$ Reianu, Politica educațională, 103-128.

${ }^{24}$ Anteproect de lege, 3.
} 
oficiile universitare, care, în viziunea autorilor documentului, aveau roluri deosebit de importante. Astfel, serviciul de cercetări era definit ca o ,unitate de cercetare fără însărcinări didactice, a cărei menire este cercetarea științifică și formarea cercetătorilor”, care putea să existe fie de sine stătător, fie ca parte a unui institut de cercetări. Un alt aspect progresist, care ducea de asemenea cu gândul la modelele de organizare din Occident (în special, la cel francez), se referea la predarea științelor experimentale nu doar în laboratoare sau clinici, ci și cu ajutorul muzeelor, „,âmpurilor de experiență” sau altor metode (de exemplu, excursii de teren etc.). La rândul său, oficiul universitar (noțiune pe care o vom regăsi sub o formă ușor modificată și în Legea din 1932) era gândit ca „o entitate administrativă, care îndeplinește servicii comune întregii universităţi sau unei singure facultăţi” ${ }^{25}$.

În ceea ce privește cursurile, acestea erau împărțite în cursuri generale obligatorii și cursuri de specializare, „menite a da studenților o pregătire științifică superioară într-o direcție anumită, fie teoretică, fie practică”. Pe lângă acestea, documentul mai prevedea ca la fiecare universitate din România să se poată organiza cursuri enciclopedice, cu caracter de sinteză, care trebuiau să ,îndrepteze neajunsurile specializării înaintate pe care o reclamă progresele culturii moderne”, acest tip de cursuri putând fi comun „mai multor facultăți sau tuturor”. De asemenea, era prevăzută și posibilitatea derulării unor cursuri sau conferințe libere și gratuite ,,asupra oricărei ramuri de științe și de către persoane care nu aparțin corpului universitar". Singura condiție în acest sens era să se obțină aprobările preliminare necesare din partea facultății, a Senatului universitar, dar și a Ministerului Educației ${ }^{26}$. Structura pregătirii universitare era și ea foarte bine detaliată în anteproiectul de lege clujean, după cum urmează: „începutul studiilor universitare se face în anul preparator, care constă în cursuri însoțite de lucrări practice de laborator și seminar. Cursurile anului preparator se pot grupa în mai multe secțiuni determinate de regulamentele Facultăților. În fiecare secțiune se predau disciplinele ajutătoare materiilor fundamentale ale licenței sau doctoratului pentru care se înscrie studentul. Nu se pot înscrie la cursurile fundamentale pentru licență sau doctorat decât studenții care au trecut examenele secțiunii corespunzătoare a anului preparator" ${ }^{27}$. $\mathrm{O}$ asemenea propunere duce parțial cu gândul la realităţile mediului universitar din Franța, unde année préparatoire reprezenta o componentă esențială a educației superioare, dar pe de altă parte poate fi interpretată și altfel decât dorința unei sincronicități cu Occidentul. Mai exact, cerința unui an de pregătire înainte de

\footnotetext{
${ }^{25}$ Anteproect de lege, 4.

${ }^{26}$ Anteproect de lege, 4.

${ }^{27}$ Anteproect de lege, 4.
} 
începerea licenței poate fi văzută și ca un semnal cu privire la diferențele existente între numeroasele tipuri de școli de nivel secundar din România Mare, diferențe care impuneau o anumită uniformizare a cunoștințelor, precum și familiarizarea cu rigorile limbajului științific și ale activității de cercetare pentru cei care își doreau să devină studenți. Pe de altă parte, aici era implicită și ideea existenței unor niveluri contrastante ale cunoașterii limbii române, mai ales în rândul minoritarilor (evrei, maghiari, germani), care trebuiau acum să își facă studiile universitare exclusiv în limba oficială a statului, adică în română.

Activitatea academică de zi cu zi urma să fie coordonată de Senatul universitar și de Consiliile Facultăților, iar în fruntea instituției, pentru „administrație și supraveghere", se afla rectorul, respectiv decanii. Propunerea făcută de clujeni pentru mandatul rectorului este una clar inspirată de practica existentă anterior, în perioada universității maghiare din urbea de pe Someș, o practică care se dovedise pe placul universitarilor, mai ales pentru că avea un caracter foarte democratic, nepermițând eventuale abuzuri de putere. Se dorea ca în universitățile românești rectorul să fie „,ales pe termen de un an, dintre profesorii titulari cu o vechime de cel puțin trei ani (...)”, iar ulterior să fie „confirmat prin decret regal”. Mai mult, se preciza că alegerea rectorului trebuia făcută „după sistemul rotaţiilor pe facultăți, rectorul neputând fi în același timp și alesul universității în Senatul țării”, iar după încheierea mandatului său, fostul rector îl putea suplini pe rectorul în funcție, în calitate de pro-rector ${ }^{28}$. Aceste prevederi se aflau în contrast destul de mare cu tradiția încetățenită în Vechiul Regat la nivelul conducerii academice, căci la Universitățile din Iaşi și București, potrivit legii învățământului superior din 1912, rectorul era „numit prin decret regal, pe termen de trei ani (...), fiind reeligibil o singură dată în continuare"29. Pentru comparație, trebuie să precizăm și că în legea din 1932, care s-a aplicat unitar la nivelul României Mari, rectorul beneficia de un mandat de cinci ani, care se putea reînnoi o singură dată în continuare, el fiind ales dintre membrii titulari ai universității ${ }^{30}$. Acest fapt demonstrează nu doar că modalitatea de desemnare a rectorului, precum și durata și prerogativele funcției sale, au reprezentat un aspect semnificativ al dezbaterilor interbelice privind reforma sistemului universitar românesc, ci și că soluția adoptată în final a fost un compromis care a favorizat modelul administrativ centralizat, al autorităților de la București, și nu pe cel existent în provinciile nou alăturate statului român.

Așa cum am afirmat deja, anteproiectul de lege întocmit de Universitatea din Cluj la începutul anilor 1920 conținea și câteva capitole foarte interesante,

\footnotetext{
${ }^{28}$ Anteproect de lege, 12.

${ }^{29}$ Antologia legilor, 180.

${ }^{30}$ Antologia legilor, 257.
} 
dedicate unor chestiuni care, de obicei, sunt reglementate prin acte normative de alt gen decât o lege organică. Avem în vedere aici secțiunile care făceau referire la construirea și întreținerea patrimoniului imobiliar al universităților sau cele privind editarea de manuale și alte publicații universitare ori implicarea în comunitate (Extensiunea Universitară). Astfel, pe lângă posibilitatea ca fiecare universitate să înființeze ateliere proprii (de mecanică, tâmplărie, legătorie de cărți, sticlărie etc.), care puteau lucra, în anumite condiții, și pentru particulari, nu doar pentru comunitatea academică sau pentru mentenanța clădirilor Almei Mater, se preconiza și crearea unui fond special de construcții, amenajări și reparații ${ }^{31}$. Acesta urma să fie coordonat de un consiliu de administrație compus dintr-un reprezentant al ministerului de Finanțe, un reprezentant al ministerului Instrucțiunii Publice/Educației, delegați ai facultăților, cărora li se alătura și reprezentantul universității în Senatul României. Documentul detalia totodată procedurile de lucru ale fondului, deși rămâneau și unele aspecte neclarificate, ca, de exemplu, ordinea sau prioritatea în care aveau să se efectueze construcțiile și/sau reparațiile ${ }^{32}$.

În privința publicării de manuale și cursuri universitare, reține atenția faptul că, în viziunea universitarilor clujeni, manuscrisele trebuiau să primească avizul facultăților de profil, iar ulterior Senatul transmitea comisiei care gestiona fondurile editoriale, ordinea în care aceste volume trebuiau tipărite ${ }^{33}$. La fel de atent era reglementată și acțiunea Extensiunii Universitare, care urma să se ocupe de ,orientarea opiniei publice cu privire la chestiunile mai importante pe care evenimentele le pun în ordinea zilei”. Cu alte cuvinte, Extensiunea avea să ofere expertiza deținută de către personalul didactic și de cercetare spre beneficiul populației generale. Concret, Senatul universitar trebuia să decidă, la fiecare început de an, care erau temele de interes pentru public, iar ulterior, la sediul universității, precum și ,„în orașele mai mari din provincia unde funcționează [aceasta]" se preconiza susținerea de cicluri de conferințe, în formă populară, de către „profesorii și agregații desemnați de consiliile facultăților cărora le aparțin”. Activitatea acestora nu era una benevolă, ci trebuia remunerată ${ }^{34}$. Ideea de popularizare a științei și culturii, de deschidere a elitelor universitare înspre mase sugera o bună cunoaștere a tendințelor mondiale din domeniul educației adulților, având în vedere faptul că la sfârșitul secolului al XIX-lea și începutul secolului al XX-lea, universitățile populare erau foarte răspândite și

\footnotetext{
${ }^{31}$ Anteproect de lege, 17-18.

${ }^{32}$ Anteproect de lege, 18-19.

${ }^{33}$ Anteproect de lege, 18.

${ }^{34}$ Anteproect de lege, 18-19.
} 
apreciate în Vestul Europei și în SUA ${ }^{35}$. De asemenea, existența acestui capitol în anteproiectul de lege atesta și interesul pentru ridicarea și uniformizarea nivelului de instruire a cetățenilor României Mari.

Foarte detaliat, pe alocuri chiar prea stufos, documentul elaborat de profesorii clujeni atestă pronunțatul spirit organizatoric al inițiatorilor săi, un spirit deja călit, așa cum am arătat anterior, în procesul de (re)fondare al universității transilvănene ca universitate românească. De aici decurg însă și anumite limite ale acestui anteproiect de lege. Dacă intenția de a extinde o serie de realități regionale sau internaționale la nivelul tuturor universităților din România este ușor sesizabilă, se acordă o mai mică atenție îmbinării în mod funcțional a realităților academice din spațiul Vechiului Regat cu cele din provinciile nou intrate în componența României Mari. Totuși, chiar și fără a analiza exhaustiv prevederile sale, putem concluziona că propunerea legislativă din 1925 a fost o inițiativă interesantă, inovatoare, care a semnalat deopotrivă autorităților și universitarilor din întreaga Românie principalele probleme cu care se confrunta lumea academică, propunând în același timp numeroase soluții concrete pentru reglementarea lor.

Ecoul acestui proiect a fost unul important în comunitatea academică, ceea ce a fost confirmat și de faptul că, în anii următori, li s-au solicitat clujenilor și alte propuneri legate de subiectul reformei și unificării sistemului universitar românesc.

De altfel, nu avea să treacă mult timp până la apariția noilor proiecte, căci în 1929, când Clujul a găzduit iarăși congresul anual al A.P.U.R., profesorul Emil Racoviță le-a prezentat colegilor o mică broșură, intitulată Câteva norme pentru organizarea universităților și a învățământului superior. Demersul său era motivat atât de un interes personal în această chestiune, cât și de rugămințile venite din partea celorlalți profesori universitari, după cum o și mărturisea: , ,afară de mandatul colegilor, m-a ademenit încă ceva la publicarea acestui sumar raport. Am constatat cu oarecare mâhnire, dar fără mirare, că chestionarele Administrației centrale, și chiar discuțiile interesaților, asupra reorganizării universitare, se mărginesc numai la cele câteva vechi probleme ce s-au vânturat de vreo sută de ani, ori de câte ori a fost vorba în vreo țară de o nouă lege a învățământului

35 Tom Steele, "A science of democracy: an outline of the development of University Extension in Europe 1890-1920" in Adult Education between Cultures. Encounters and identities in European adult education since 1890, ed. Barry J. Hake and Stuart Marriott (Leeds: University of Leeds, 1992), 61-85; Janet Coles, "University Extension in the United States: the English connection" in Adult Education between Cultures. Encounters and identities in European adult education since 1890, ed. Barry J. Hake and Stuart Marriott (Leeds: University of Leeds, 1992), 113-130. 
superior. [...] Mă mâhnește indiferența multor colegi față de necesitatea de a armoniza organizarea universitară cu stadiul actual al dezvoltării științei și al nevoilor obștești”36.

Spre deosebire de anteproiectul de lege foarte stufos, elaborat la începutul anilor 1920 de către Universitatea din Cluj, documentul redactat de Emil Racoviță era mult mai sintetic, dar și mai conceptual, dovedind calitățile și viziunea de om de ştiință a acestuia. Astfel, el susținea că în lege trebuiau să fie trasate doar principii sau norme generale, iar detaliile și aplicarea acestora trebuiau să fie realizate prin intermediul unor regulamente. Totodată, Racoviță pleda pentru păstrarea unui anumit specific local și/sau regional în procesul de dezvoltare și funcționare a universităților românești: „nu trebuie o lege calup, în care să fie cu sila ticsite toate universitățile noastre. Trebuie să permitem ca fiecare universitate să își formeze personalitatea sa, fizionomia sa proprie. Nu ne trebuie un model de universitate în patru exemplare cu exact aceleași catedre, servicii, institute și oficii. Vrem universități nesimetrice, fiecare dezvoltându-se liber în partea ei cea mai vitală (...), vrem într-un cuvânt o dezvoltare firească după năzuințele, nevoile, aptitudinile și puterile locale, și nu o alcătuire artificială după șabloane birocratice" 37 .

Structurat în șapte mari părți, proiectul lui Racoviță puncta cele mai importante elemente care contribuiau la bunul mers al instituțiilor academice. Viziunea sa privind organizarea administrativă a universității era oarecum asemănătoare cu propunerile anterioare ale clujenilor. În opinia sa, universitatea (și implicit facultățile, ca entități secundare ale universităților) era alcătuită din: „catedră, servicii, institute și oficii”. Așadar, serviciul și oficiul sunt unități organizatorice pe care și profesorul Racoviță le considera utile și necesare în cadrul Almei Mater, însă definițiile pe care le dădea acestora erau mai nuanțate decât cele propuse în anteproiectul de lege din 1925. Potrivit lui Racoviță, serviciul era ,unitatea didactică a disciplinelor cu laborator. Anexele acestor unități sunt laboratoarele, clinicile, câmpurile de experiențe, stațiunile de cercetări temporare și permanente, muzeele etc.” ${ }^{38}$. Putem remarca, aşadar, că savantul clujean acorda o importanță sporită dimensiunii practice a formării studenților și, de asemenea, că, pentru Emil Racoviță, serviciul universitar reprezenta echivalentul catedrelor teoretice, beneficiind de numeroase facilități care să asigure performanța didactică și științifică. Față de varianta legislativă anterioară, în care se vorbea despre serviciu, subliniem că în această versiune atribuțiile sale

\footnotetext{
${ }^{36}$ Emil Racoviță, Câteva norme pentru organizarea universităților și a învățământului superior (Cluj: Congresul A.P.U.R., 1929), 1-2.

${ }^{37}$ Racoviță, Câteva norme, 1-2.

${ }^{38}$ Racoviță, Câteva norme, 3.
} 
erau sporite, extinse, rolul acestuia nefiind limitat doar la efectuarea de cercetări. În mod aproape vizionar, am spune, Racoviță înțelegea că viitorul avea să aducă o pondere din ce în ce mai mare disciplinelor aplicate, așa zisele științe „dure” (hard sciences) în universitate, ceea ce explică locul privilegiat pe care l-a rezervat serviciilor în ierarhia organizațională a universității.

Cât privește oficiile universitare, aici concepția lui Racoviță era destul de apropiată de cea oferită în documentul din 1925. Profesorul vedea oficiile drept „entități administrative simple sau compuse, subordonate facultății din care face parte sau universității”39.

La nivelul conducerii universitare Emil Racoviță rămânea credincios tradiției clujene deja încetățenite, anume concepției care prevedea ca rectorul să dețină funcția doar pentru câte un an. Exista însă și o modificare semnificativă în acest sens. Astfel, apărea posibilitatea realegerii rectorului (ceea ce sugera implicit și o mai mare eficiență administrativă), fără însă a se preciza dacă era vorba despre mandate consecutive sau exercitate la un anumit interval ${ }^{40}$.

Modernitatea gândirii profesorului Racoviţă era dovedită și de modul în care a conceput programa de învățământ universitar. Proiectul său din 1929 apare astăzi drept surprinzător de similar cu sistemul Bologna, cu ciclurile sale de Licență-Masterat-Doctorat. Dar ce propunea, în mod concret, marele savant? El susținea, cu argumente întemeiate, necesitatea împărțirii disciplinelor universitare în două mari categorii, anume discipline fundamentale și, respectiv, discipline de specialitate. Materiile fundamentale corespundeau „primelor diviziuni ale științei: Zoologia, Botanica, Fizica, Geologia, Chimia minerală (....), Istoria universală, Dreptul civil...”. Aceste discipline trebuiau să fie predate numai pentru pregătirea licenței. Prin contrast, disciplinele de specialitate, înțelese ca niște ,,entități recente care se înmulțesc mereu, paralel cu dezvoltarea cunoștințelor și cu nevoile de specializare și de diviziune a muncii în cercetări, de exemplu: Citologia, ecologia, radiologia, hematologia (...) subdiviziunile istoriei, filologiei, etc.” urmau să pregătească studenții „,doar pentru diplomele superioare licenței”"11. Totodată, Racoviță atenționa asupra unor fenomene inevitabile, care constituiau, în același timp, și un posibil factor de risc: „,̂nmulțirea progresivă a catedrelor și serviciilor este fatală și necesară; ea este foarte prielnică dezvoltării cunoștințelor dacă se stabilește distincția între discipline propusă mai sus; altfel se va ajunge la falimentul desăvârșit al învăţământului superior” $^{\text {”2 }}$. În puține cuvinte, Emil Racoviță punea, așadar, un diagnostic foar-

\footnotetext{
${ }^{39}$ Racoviță, Câteva norme, 3.

${ }^{40}$ Racoviță, Câteva norme, 3.

${ }^{41}$ Racoviță, Câteva norme, 9.

${ }^{42}$ Racoviță, Câteva norme, 10.
} 
te corect lumii universitare, iar capacitatea sa de anticipare privind evoluția sistemului academic din România îi confirmă, dacă mai era nevoie, competența științifică deosebită. Regăsim în considerațiile lui Racoviță despre universități un ecou al ideilor și conceptelor pe care savantul clujean le exprimase în lucrările despre evoluționismul lumii naturale, un subiect căruia îi dedicase multe ore de cercetare. Astfel, în volumul Evoluția și problemele ei, apărut tot în 1929, profesorul Racoviță afirma următoarele ,trebuie să ne adaptăm evoluționismului integral, trebuie să ne croim mentalitatea, viața individuală, organizarea socială pe noțiunea de evoluție"43. Veridicitatea observațiilor lui Racoviță despre lumea academică fac ca acestea să rămână actuale chiar și în prezent, putând servi ca bază de discuție pentru alte reforme ale învățământului superior.

Multe alte asemănări și deosebiri pot să fie decelate pe parcursul unei analize comparative a propunerilor legislative lansate de universitarii clujeni în anii 1920. Ceea ce merită însă reținut, înainte de toate, este implicarea lor profundă în dezbaterile dedicate înfățișării pe care trebuia să o primească lumea universitară în cadrul României de după 1919. Se poate spune că majoritatea inițiativelor pe care le-au avut, la fel ca și pozițiile și intervențiile lor din presă sau din Parlament, au dovedit dorința realizării unor instituții solide, care să se afle, pe cât era posibil, în sincronicitate cu statutul și modul de funcționare al universităților din restul continentului european În același timp, documentele elaborate de profesorii de la Cluj au servit, la momentul publicării lor, drept bază de discuție printre colegii universitari din țară, impulsionând totodată și apariția altor proiecte asemănătoare, provenite de la universitățile din Cernăuți (în 1930), București (în 1931) sau Iași.

Toate anteproiectele elaborate până la adoptarea legii învățământului superior din 1932 (deocamdată fiind identificate 6 asemenea acte ${ }^{44}$ ) atestă, în opinia noastră, faptul că în România Mare a existat o reală discuție publică pe tema reformei universităților, că profesorii universitari, la fel ca și alți actori din domeniu, s-au simțit și responsabilizați, și auziți de către autorități, dincolo de orice divergențe politice sau de altă natură. În pofida controverselor, a ezitărilor sau amânărilor, legile universitare adoptate în 1931 și 1932 au reprezentat o încercare, nu complet reușită, de a păstra un echilibru între specificul regional al universităților din Cluj și Cernăuți, marcate de o practică și de o tradiție academică diferită de cea din Vechiul Regat, mai occidentalizată în unele privințe, și tendința de centralizare și integrare într-un model educațional comun, în cadrul căruia statul și-a păstrat un rol de control destul de important. Pe lângă

\footnotetext{
${ }^{43}$ Emil Racoviță, Evoluția și problemele ei (Cluj: Astra, 1929), http://emil-racovita.speosub.ro/ biologie/evolutia-si-problemele-ei/

${ }^{44}$ Reianu, Politica educațională, 131-132.
} 
anumite limitări sau ingerințe ale autorităților, prevederile legislației interbelice au fost totuși unele democratice, obținute și adoptate în urma unor consultări reale, iar drept urmare universitățile românești au beneficiat de o reală autonomie și libertate de funcționare. Această evoluție spre performanțe științifice și didactice, dar și înspre o sincronicitate cu tendințele academice internaţionale avea să fie brutal întreruptă odată cu instaurarea comuniștilor în România după cel de-al doilea război mondial. Astfel, prin decretul-lege nr. 658 din 24 august 1946 autonomia universitară avea să fie anulată, iar legea pentru reforma învățământului din 3 august 1948 a consfințit ingerința politicului în actul educațional, modificând complet forma și spiritul sistemului universitar românesc, unele consecințe fiind resimțite și în prezent. Cercetări ulterioare, mai aprofundate, sunt desigur necesare pentru a ajunge treptat la o imagine de ansamblu asupra lumii academice interbelice din România, a felului în care s-a realizat procesul decizional în și despre universități, și pentru a putea apoi compara realizările (sau eșecurile) acestor instituții cu cele ale universităților din alte țări europene.

\section{Rezumat}

După Marele Război și unirea Basarabiei, Bucovinei, Transilvaniei și Banatului cu Vechiul Regat, reforma învățământului superior românesc și, implicit, transformarea acestuia într-un sistem unitar şi eficient a necesitat multe eforturi. Un număr semnificativ de inițiative și proiecte au fost discutate de cercurile academice românești, de politicieni și de publicul larg, înainte de adoptarea și implementarea primei legi pentru organizarea universităților din România Mare, în aprilie 1932. Acest articol este un studiu de caz, care se apleacă asupra a două propuneri prezentate în anii 1920 de unii profesori proeminenți ai Universității din Cluj. Cercetarea mea încearcă să clarifice și să îmbogățească cunoștințele noastre despre diferitele etape care au precedat și modelat legea învăţământului superior din 1932. Ea evidențiază asemănările și diferențele dintre aceste proiecte, examinând, în special, elementele lor cele mai relevante și mai moderne. Articolul oferă în egală măsură puncte de comparație pentru viitoare analize privind reconstrucția sistemelor educaționale din alte țări ale Europei Centrale și de Est, în prima jumătate a secolului al XX-lea.

Cuvinte cheie: reforma universităților românești, perioada interbelică, inițiative legislative, Universitatea românească din Cluj, Emil Racoviță, Legea învățământului superior din 1932.

Ana-Maria Stan, Babeș-Bolyai University of Cluj-Napoca (Romania). Email: ana.stan@ubbcluj.ro 